\title{
Crisis of Fresh Water in South 24 Parganas District, West Bengal: Causes and Consequences
}

\author{
Mausumi Bandyopadhyay ${ }^{1}$ and Ranjan Basu ${ }^{2}$ \\ Assistant Professor ${ }^{1}$ and Professor ${ }^{2}$ Department of Geography \\ GMSM Mahavidyalaya,Bireswarpur, South 24 Parganas $^{1}$ University of Calcutta, Kolkata $^{2}$
}

\begin{abstract}
Water scarcity occurs due to inadequacy of fresh water. It may be a physical problem initially having reflection on socio-economic profile of a community; but it affects productivity and prosperity of the people in a region. It is very difficult to overcome physical constraint of water scarcity as it depends on geohydrology, but proper management strategy is conducive for addressing the problem. South 24 Parganas district of West Bengal is located on the southern part of Ganges Delta. So the region is endowed with huge quantity of surface and ground water. But the typical geo-hydrology, sea water ingression, soil salinity and high content of soil clay create major problems. The management strategy adopted for this precious resource in this district is not up to the mark. So the local people have to suffer all the year round especially during the xeric period and because of waterlogging during the rainy season.

In case of surface water, the volume of sweet water in river Hooghly and its tributaries are gradually decreasing and sea level is gradually rising; consequently the salinity in soil and water is gradually increasing. Among the two ground water aquifers, the upper one $(70$ to $160 \mathrm{~m} \mathrm{bgl}$ ) is brackish in nature, so it is not suitable for use. The depth of another ground water layer is more than 160 metre below the ground level almost all over the district. Lifting of this fresh water for drinking and irrigation is too costly. Administrative initiative has been taken to supply this fresh water for drinking purpose through installation of hand pumps or tube wells. Providing irrigation water free of cost is not cost effective and therefore most of the cultivators do not get water for irrigation harnessing the aquifer level due to lack of capabilities to install deep tube wells. The consequences of this scarcity is socio-economic in nature. Poverty, loss of agricultural and piscicultural productivity, absence of large scale industry, and high morbidity of various water-borne diseases are the direct effects of such scarcity of fresh water.

The present paper is an endeavour to find out the causes of fresh water scarcity and to focus on its impact on the people and environment in the fragile ecosystems on the area under study.
\end{abstract}

Key words: water scarcity, ground water aquifer, water quality index, water borne diseases, fragile ecosystems

\section{INTRODUCTION}

Water for life and livelihood are two most important foundations that can make or break the human development. Non availability of clean water is more harmful than any war. Deprivation from clean water is a silent crisis that does not draw any media attention like war, poverty or hunger. But it equally makes human lives and livelihood vulnerable and unsecured. For overcoming this crisis United Nations fixes up target of ensuring 20 litters of clean water per person per day as a Millennium Development Goal within 2015, after which Sustainable Development Goal is fixed. The goal is to ensure availability and sustainable management of water and sanitation for all within 2030. Now access to clean water is treated as human right also.

Worldwide scenario of water crisis differs from rich to poor countries. Almost everyone in the developed world has access to safe water in contrast to the position in developing countries. Water threshold is different in rural and urban areas too.South 24 Parganas District of West Bengal in India faces crisis of fresh and potable water amidst plenty of water available in a deltaic riverine plain. This contradiction is due to both physical and socioeconomic constraints. The scarcity of water makes quality of life substandard in this district.

\section{OBJECTIVES}

The objectives of this present study are:

- To identify the fresh-water aquifer zone prevailing in the district

- To analyse the spatio-temporal variation in depth of ground water

- To detect the utilisation pattern of fresh water

- To calculate the Water Quality Index and its variation in different blocks

- To find out the consequences of water scarcity in the area under study

$\bullet$

DOI: $10.9790 / 0837-2206040415$

www.iosrjournals.org

$4 \mid$ Page 


\section{AREA UNDER STUDY}

South 24 Parganas District of West Bengal has latitudinal extension between $21^{\circ} 29^{\prime} \mathrm{N}$ and $22^{\circ} 33^{\prime} 45^{\prime \prime} \mathrm{N}$ on one hand and longitudinal extension between $88^{\circ} 3^{\prime} 45^{\prime \prime} \mathrm{E}$ and $89^{\circ} 4^{\prime} 50^{\prime \prime} \mathrm{E}$ on the other. Area of the district is 9,960 sq. $\mathrm{km}$. It has seven municipalities and 29 community development blocks. Bangladesh is located in the east of the District, East Medinipur and Haora District of West Bengal lie in the West, while Kolkata and North 24 Parganas District lie in the north and Bay of Bengal is in the south of the study area.



Fig-1Source: NATMO

The district has rich endowment of natural, social, cultural and economic resources, but, the quality of life is in the phase of 'Struggle for existence'. Natural resource base includes soil, land, water and forest of the mainland and the island ecosystems. Sunderban Biosphere Reserve, located in the southernmost part of the District is a UNESCO world heritage site. Socio-economic resources include human resource, agricultural crops, fresh and saline water fish, household industry products and range of infrastructure. Diversity and disparity prevail in between rural-urban and mainland-island environment. The major causes of backwardness of this district is underutilisation of resources and not scarcity of resources. 


\section{MATERIALS AND METHODS}

For the present study both primary and secondary data have been collected. Secondary data have been collected from District Statistical Handbook (2014), Census of India (2011), Socio-economic and Caste Census2011, India Meteorological Department, State Water Investigation Department, and Central Ground Water Board. data for present study have been generated from 29 Community Development blocks and seven Municipalities on the basis of pre-designed questionnaire following the purposive method of sampling. Various methods have been followed in order to make assessment of the water resource such as spatio-temporal analysis of the depth of ground water and computation of Water Quality Index. For calculation of Water Quality Index (WQI), five parameters have been chosen. These are $\mathrm{pH}$, hardness, chloride, iron content, along with total dissolved solids. The WQI have been worked out by using standard of drinking water quality recommended by World Health Organisation (WHO), Bureau of Indian Standard (BIS), and Indian Council of Medical Research (ICMR). The Water Quality Index is a weighted arithmetic index proposed by Brown et. al. (1972) which may be summarised in the following steps:

1) Calculation of sub-index by the formula $q_{n}=100(\mathrm{Vn}-\mathrm{Vio}) /(\mathrm{Sn}-\mathrm{Vio})$

Here, $\mathrm{q}_{\mathrm{n}}-$ Quality rating or sub-index $\left(\mathrm{q}_{\mathrm{n}}\right)$

Vn-Estimated value of the nth parameter

Sn-Standard permissible value

Vio- Ideal value of the pure water (i,e, 0 for all parameters except $\mathrm{pH}$ (7) and Dissolved Oxygen (14.6 mg/l)

II) Unit weight was calculated by a value inversely proportional to the recommended value $\mathrm{Sn}$ of the corresponding parameter

$\mathrm{Wn}=\mathrm{K} / \mathrm{Sn}$

Wn- Unit Weight

$\mathrm{Sn}=$ Standard permissible value

$\mathrm{K}$ - Constant of the proportionality

III) The overall WQI was calculated by aggregating the quality rating with the unit weight linearly $\mathrm{WQI}=\sum \mathrm{q}_{\mathrm{n}} \mathrm{Wn} / \sum \mathrm{Wn}$

Water Quality Index and Status of Water Quality (Chatterjee and Raziuddin, 2002)

\begin{tabular}{|c|l|}
\hline Water Quality Index Level & Water Quality Status \\
\hline $0-25$ & Excellent Water Quality \\
\hline $26-50$ & Good Water Quality \\
\hline $51-75$ & Poor Water Quality \\
\hline $76-100$ & Very Poor Water Quality \\
\hline$>100$ & Unsuitable for Drinking \\
\hline & \\
& \\
\hline & \\
\hline
\end{tabular}

\section{RESULTS AND DISCUSSION}

Two types of water scarcity are conspicuous in this district.1) Physical dimension of water scarcity: It is the lack of natural water resources and totally depends on the hydro-geology of the area. Surface soil also plays a crucial role in ground water recharge. In the rainy season the district gets sufficient rainfall, but the drainage condition is so poor that the water cannot flow downward due to thick clay content. Waterlogging persist for a long period every year. Using this rainwater staple food rice is grown every year. But after rainy season the soil becomes dry quickly. During the winter, soil becomes so dry that agriculture is not possible without supply of water from external sources. Few people cultivate their land using pond water by different devices. But most of the arable land lies vacant as current fallow.2) Economic dimension water scarcity: Water scarcity in this district has economic dimension too which takes place due to wastage of rainwater. In case it is possible to make harvesting of excess rainwater then it can be possible to use it during the xeric periods of winter and pre-monsoon seasons. But, irrigation is mainly dependent on pond water for Rabi crops in winter.

\section{DISTRICT-LEVEL PHYSICAL CHARACTERISTICS}

Being the second most populous district of West Bengal, South 24 Parganas rely on fresh surface and ground water for drinking, household, agriculture, fishing and industrial use. Though the district is located on tropical monsoon region with average annual rainfall of $1,762 . \mathrm{mm}$, the distribution is, skewed and concentrated on monsoon months spread over June to September. Rest of the months in the span of a year the district suffers from water crisis. The spatio-temporal variation in the distribution of fresh and brackish water totally follow the hydro-geomorphology of the Ganga Delta Plain. 


\section{PHYSIOGRAPHY:} follows:

The district comprises of deltaic alluvial plain. Major physiographic divisions of the area are as

A) Low lying flood plain: This flood plain is located in the interfluves of Hooghly- Raimangal and formed due to fluvial action of the tributaries of these two rivers.B) Paleo-channels: Paleo-channels are the river beds of the dry or deceased rivers. River bed of Adi Ganga is a paleo-channel flowing through Tollygunge, Garia, Baruipur and Jaynagar while fresh water aquifer level is high below the ground level along this paleo-channel. C) Deltaic Plains: It occupies the southern portion of the District formed by the tidal action and traversed by spill channels of the river Hooghly and other tidal creeks.

Drainage:

The Drainage system includes two types of rivers, such as:

i) Fresh water bearing rivers - Hooghly on the west and Ichhamati- Raimangal in the east. ii) The tidal rivers Matla, Vidya, Gosaba, Thakuran, Vidyadhari, etc. Apart from the rivers there are various waterbodies like ponds, lakes, canals and creeks.

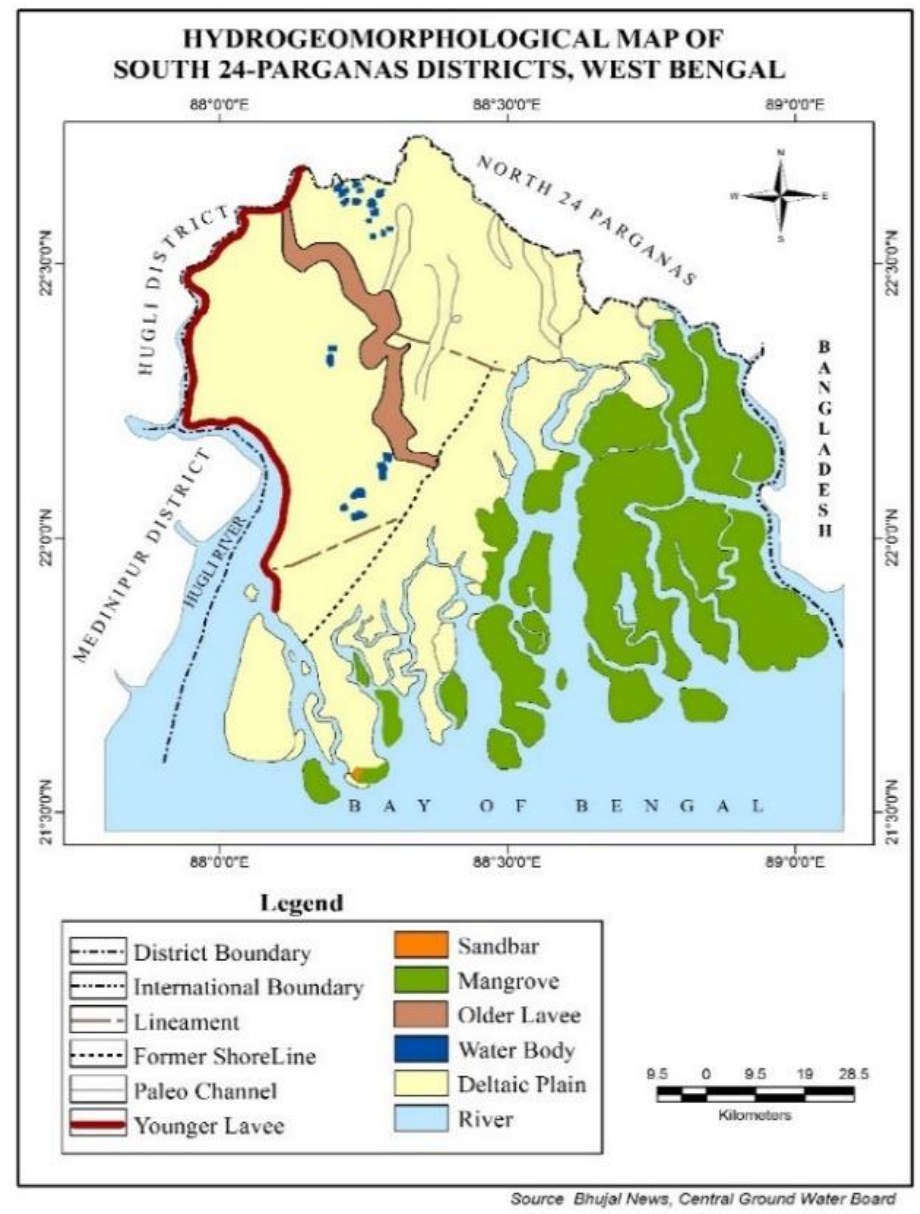

Fig-2

Aquifer Disposition:

The most important aquifers in South 24 Parganas District belong to the unconsolidated sediments of quaternary and upper tertiary period deposited under fluvial and submarine to marine segments. The aquifers containing water in the area reveal a succession of coarse to fine grained sand, clay and kankar along with their various admixtures with localised patches of gravel and cemented sand grains. The top surface is composed of a clay layer, thickness of which varies from 15 to $70 \mathrm{~m}$. Below the clay layer fine to coarse sand, gravels, silt and clay exists. Generally groundwater occurs here under confined condition at a depth ranging between 20 and $400 \mathrm{~m}$ with numerous alteration of clay and sandy clay beds of varying thickness. (Bhu-JalNews, Volume-24, Number-1, 2009). Generally the upper group of aquifers contain saline water at a depth of 20-168m and fresh water bearing aquifer occurring within 160-360 m below ground level. Exception has been seen in the paleo- 
channels as well as and in Bhangar-I and Bhangar-II blocks the uppermost aquifer is fresh in nature with a depth of $50 \mathrm{~m}$ below the ground level. Salinity in these aquifers is due to $\mathrm{NaCl}$ concentration derived from sea water ingress and salt water entrapped in the sediments under marine conditions in late Pleistocene to early quaternary period when shallow marine condition prevailed in the deeper parts of the Bengal Basin. The salinity gradually decreases from the coastal areas to the inland areas. (Bhu-JalNews, Volume-24, Number-1, 2009).



Fig-3

Water Resource of the District:

The total water resource is the assimilation of three types of water; i) Precipitation ii) Replenishable ground water iii) Runoff from the neighbouring Districts.

\begin{tabular}{|c|c|c|c|}
\hline \multicolumn{4}{|c|}{ Table- 1:District-wise Estimation of Water Resources } \\
\hline District & $\begin{array}{c}\text { Annual resources } \\
\text { from Rainfall } \\
(\mathrm{bcm})\end{array}$ & $\begin{array}{c}\text { Annual resources from } \\
\text { Upstream runoff } \\
(\mathrm{bcm})\end{array}$ & $\begin{array}{c}\text { Annually replenish able } \\
\text { Ground water including } \\
\text { discharge (bcm) }\end{array}$ \\
\hline Darjiling & 5.78 & 16.25 & 0.54 \\
\hline Jalpaiguri & 11.30 & 32.56 & 2.69 \\
\hline Koch Bihar & 6.42 & 44.18 & 2.44 \\
\hline Uttar Dinajpur & 3.31 & 16.86 & 1.94 \\
\hline Dakshin Dinajpur & 1.55 & 18.64 & 1.15 \\
\hline
\end{tabular}




\begin{tabular}{|l|c|c|c|}
\hline Maldah & 2.14 & 553.21 & 1.69 \\
\hline Murshidabad & 0.54 & 561.88 & 3.25 \\
\hline Birbhum & 1.46 & 4.50 & 2.43 \\
\hline Bardhaman & 1.84 & 45.54 & 4.40 \\
\hline Nadia & 0.27 & 48.25 & 2.81 \\
\hline North 24 Parganas & 1.91 & 50.33 & 1.93 \\
\hline Hugli & 0.59 & 65.28 & 2.28 \\
\hline Bankura & 2.06 & 13.35 & 2.85 \\
\hline Puruliya & 3.68 & 9.60 & 0.93 \\
\hline Purba Medinipur & 3.27 & 76.68 & 0.95 \\
\hline $\begin{array}{l}\text { Paschim } \\
\text { Medinipur }\end{array}$ & 2.36 & 3.6 & 4.63 \\
\hline Haora & 0.96 & 67.36 & 0.49 \\
\hline South 24 Parganas & 1.86 & 81.03 & 4.70 \\
\hline Kolkata & 0.25 & 50.07 & 0.00 \\
\hline West Bengal & 51.02 & 598.56 & 34.20 \\
\hline
\end{tabular}

Source: Report of the West Bengal Pollution Control Board, 2009

Analysing the table-1 it is evident that South 24 Parganas District possesses a good quantity of water resources especially from upstream runoff and Ground water. But due to mismanagement it cannot be utilised properly. Spatio-temporal Variation in the Depth of Ground Water: The depth of the ground water and its spatio-temporal variation in pre-monsoon and post-monsoon season is revealed by the investigation from a number of bore holes in different C.D. blocks executed by the State Water Investigation Department, Government of West Bengal and Central ground water Board.Analysing depth of the ground water in case of pre-monsoon season it has been observed that, water level varies from two metre to ten metre below the ground level. The water level is nearer the ground level in the lower part of the deltaic plain than its upper part. The same is true in case of post monsoon ground water level. Ground water exploitation is effected by salinity hazard in all over the district. (Das-2011).

\section{Year-wise Variation in Depth of Ground Water (Pre-Monsoon)}

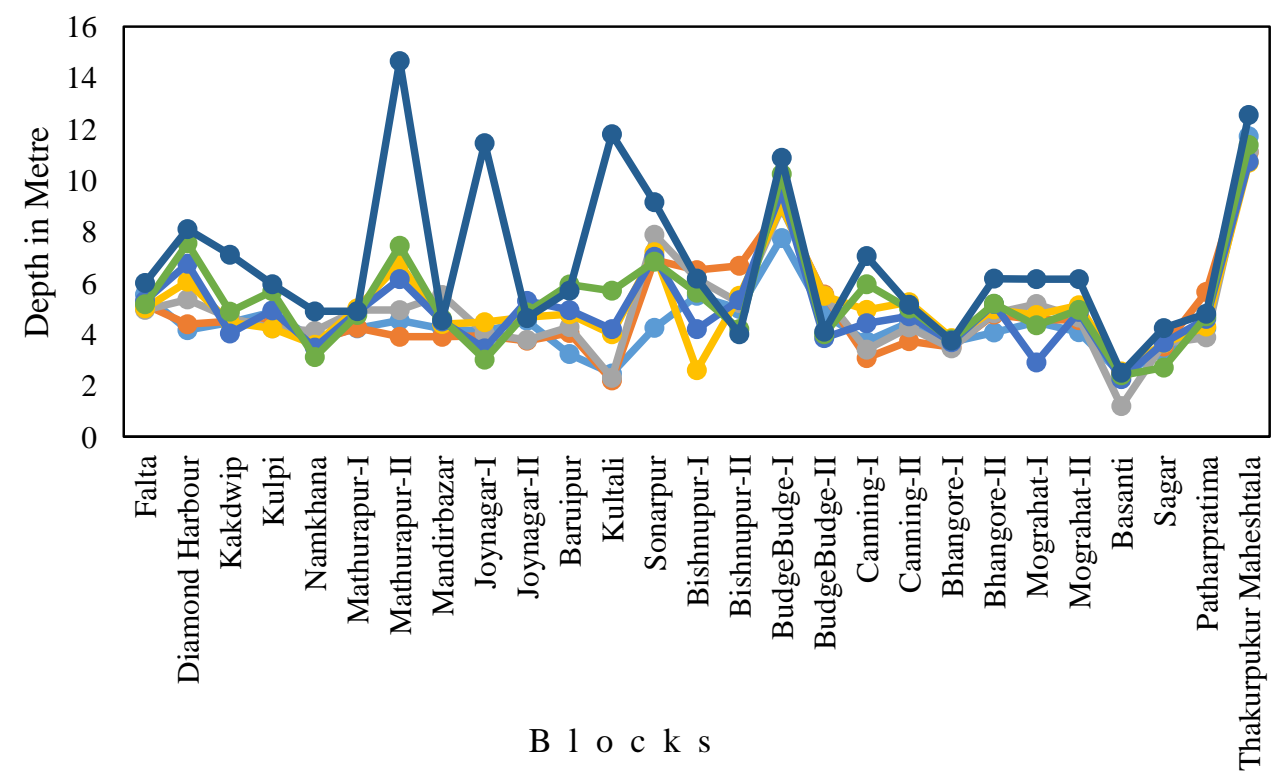

$-2001-2003-2004-2006-2007-2009-20$

Fig-4Source: State Water 




Investigation Department

Fig-5Source: State Water Investigation Department

Use of Fresh Water:The use of fresh water has been categorised into the following; a). Drinking b). Domestic purpose c). Ecological services (inclusive of sustenance of forest and wetlands) d). Agriculture e). Industry and f) Navigation

Impact of Water Scarcity on Utilisation of Water Resources:

a)Drinking Water:

The drinking water is collected from 160 to $360 \mathrm{~m}$ deep fresh water bearing aquifer. From the census 2011 apart from Socio-economic and Caste Census it has been observed that main source of drinking water is hand pump in C.D. Blocks. These hand pumps have been installed by the government authorities. But in most of the municipalities people get pipeline water supplied by the municipal authorities.

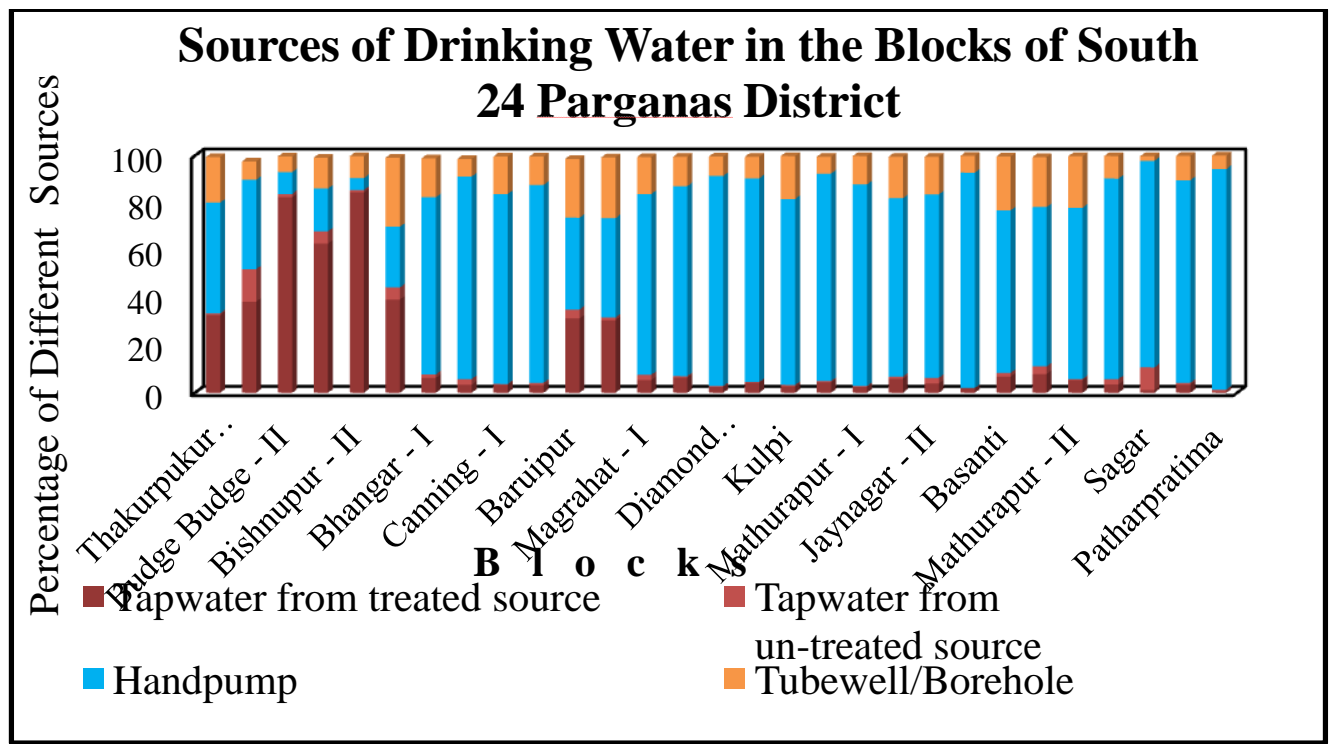

Fig-6Source: Socio-economic and Caste Census (2011)

Exception is observed in Diamond Harbour and Joynagar Municipalities. These two municipalities are located far away from Kolkata. In the slum areas of these municipalities people have to collect water from hand pump which are located at a distance from households. From primary data analysis it is evident that in the mainland blocks), location of the hand pumps is 100 to $200 \mathrm{Mt}$ away, but in the Sundarban island blocks most of the households collect water from distant places 


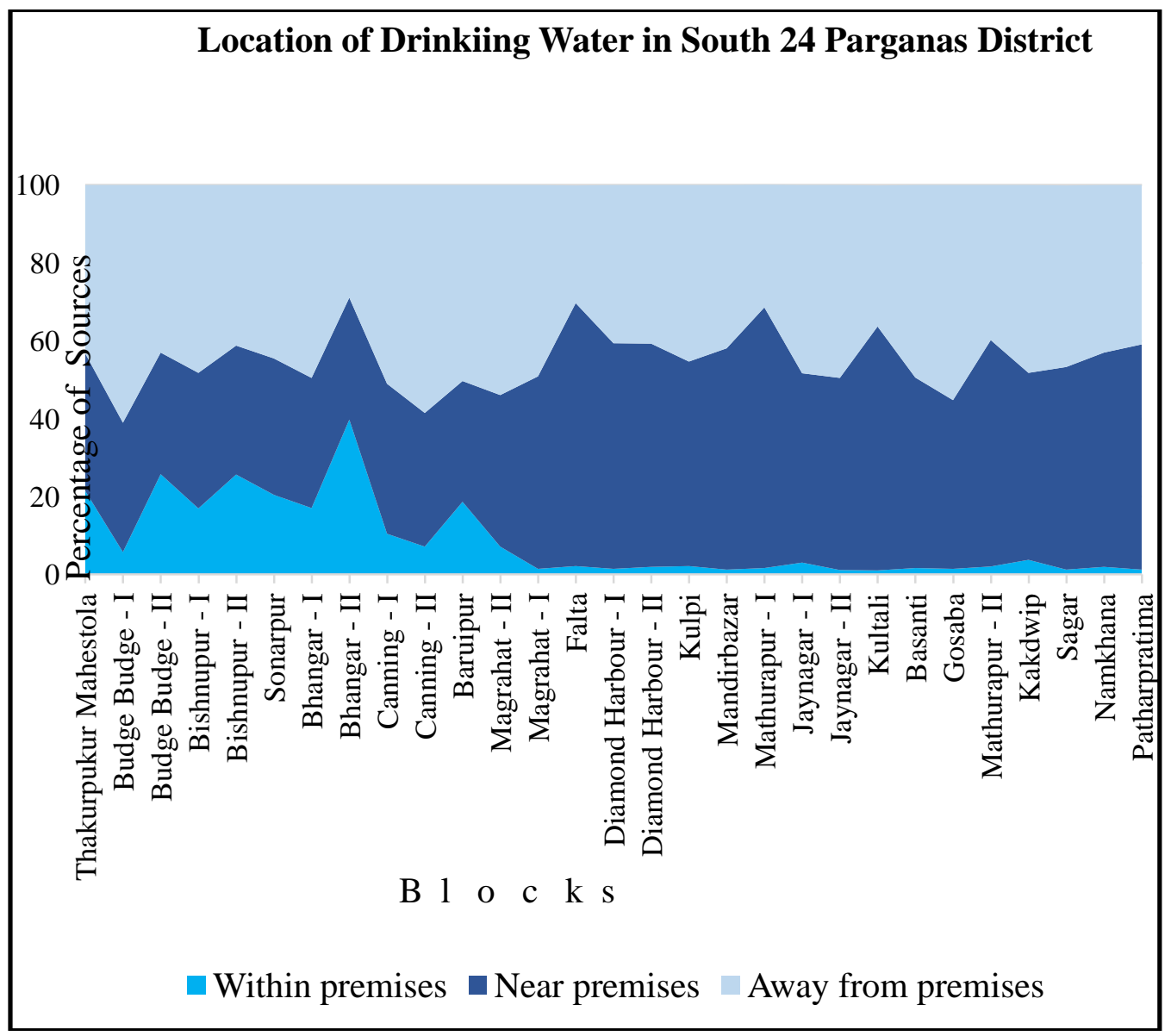

Fig-7Source: Census of India (2011)

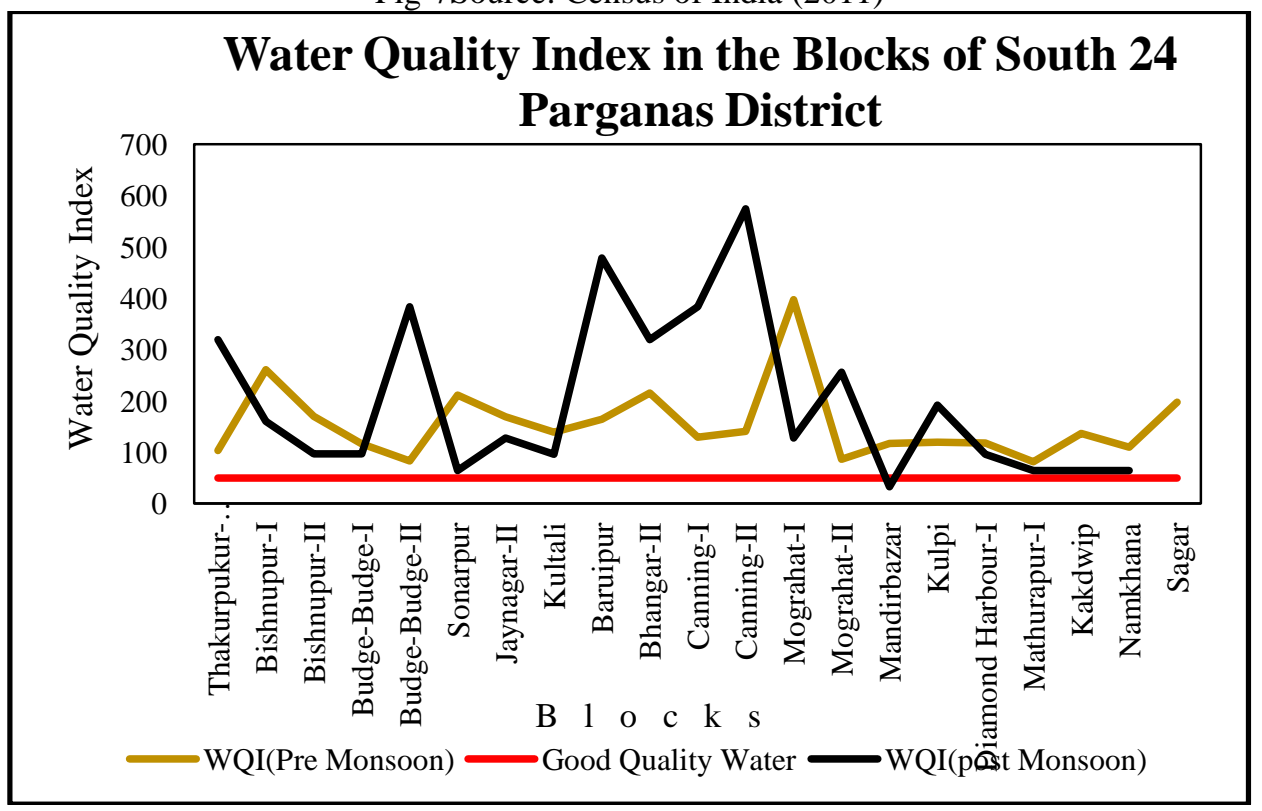

Fig.8Source: Computed by the authors from data provided byState Water Investigation Department

The quality of drinking water in block level have been analysed by Water Quality Index. From the Fig- 8 it is evident that both in pre-monsoon and post-monsoon seasons the quality of water is unsuitable while the value exceeds desired level. This is because mainly of higher $\mathrm{pH}$ value along with higher quantity of iron, total dissolved solids, and chloride in drinking water. Post-monsoon water quality is alarming in the blocks of 
Baruipur, Bhangar I and Bhangar-II, Canning-I and Canning-II. Baruipur, Sonarpur, Bhangar-I and Bhangar-II, Mograhat-I and Mograhat-II blocks suffer from the problem of arsenic contamination in drinking water.

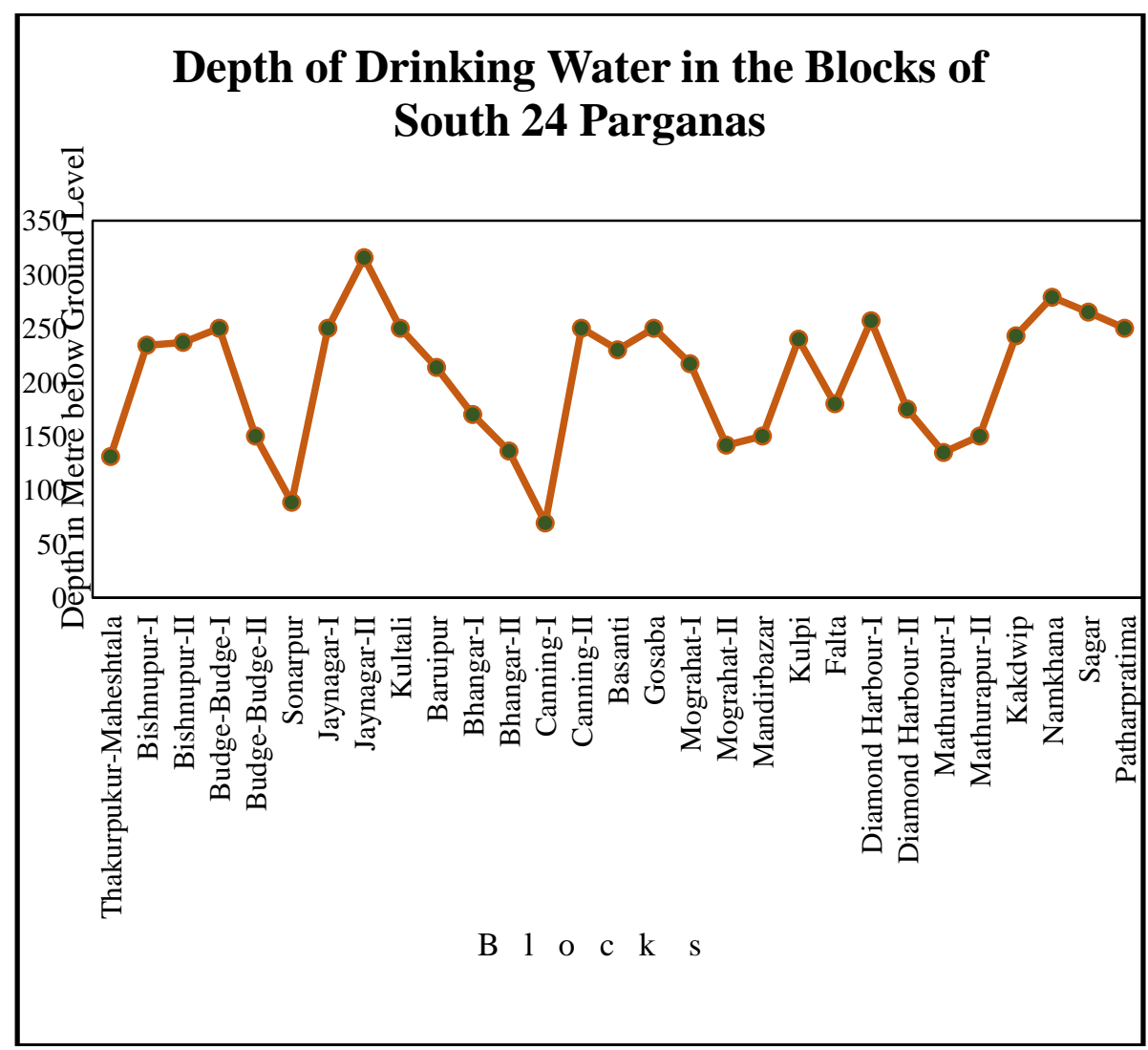

Fig-9Source: Central Ground Water Board

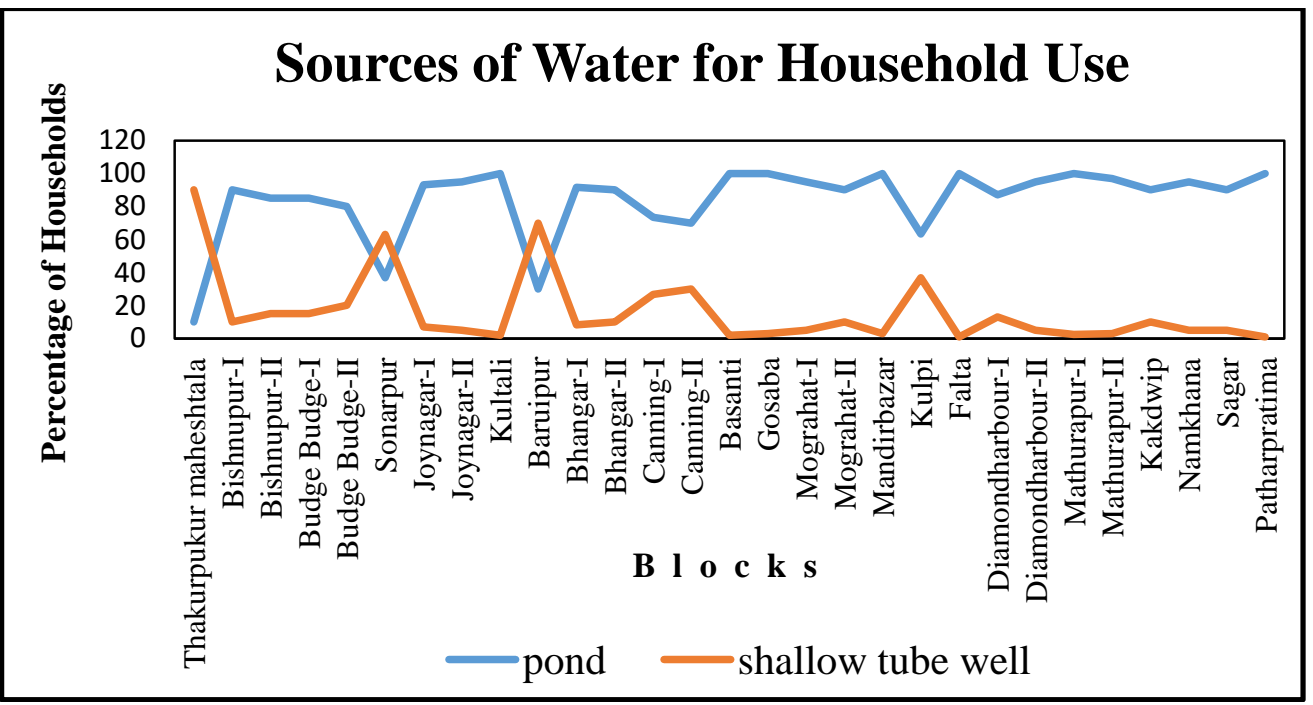

Fig-10 Source: Primary Data, 2017

b)Water for Domestic Use:

Domestic water means the water used in household for cooking, cleaning, washing, bathing, gardening, for use of the domestic animal and for other purposes. Domestic water used in this district is mainly pond water in all C.D. blocks and in two municipalities that is Jaynagar and Diamond Harbour. The quality of water is obviously unsuitable for use, but people are compelled to use this for absolute scarcity of fresh water. In Gosaba, the pond water though saline, all the rural folk use it for household and domestic animals also consume it. 
c) Ecological Services:

From the point of biodiversity conservation it is necessary to preserve wetlands and forests. The demand of water for forests is calculated from available rainfall. Annual water demand for the forests of South 24 Parganas District is 7692.93 MCM and the supply is 7369.02 MCM (Department of Forests, Govt. of West Bengal). So water scarcity prevail in this sector too.

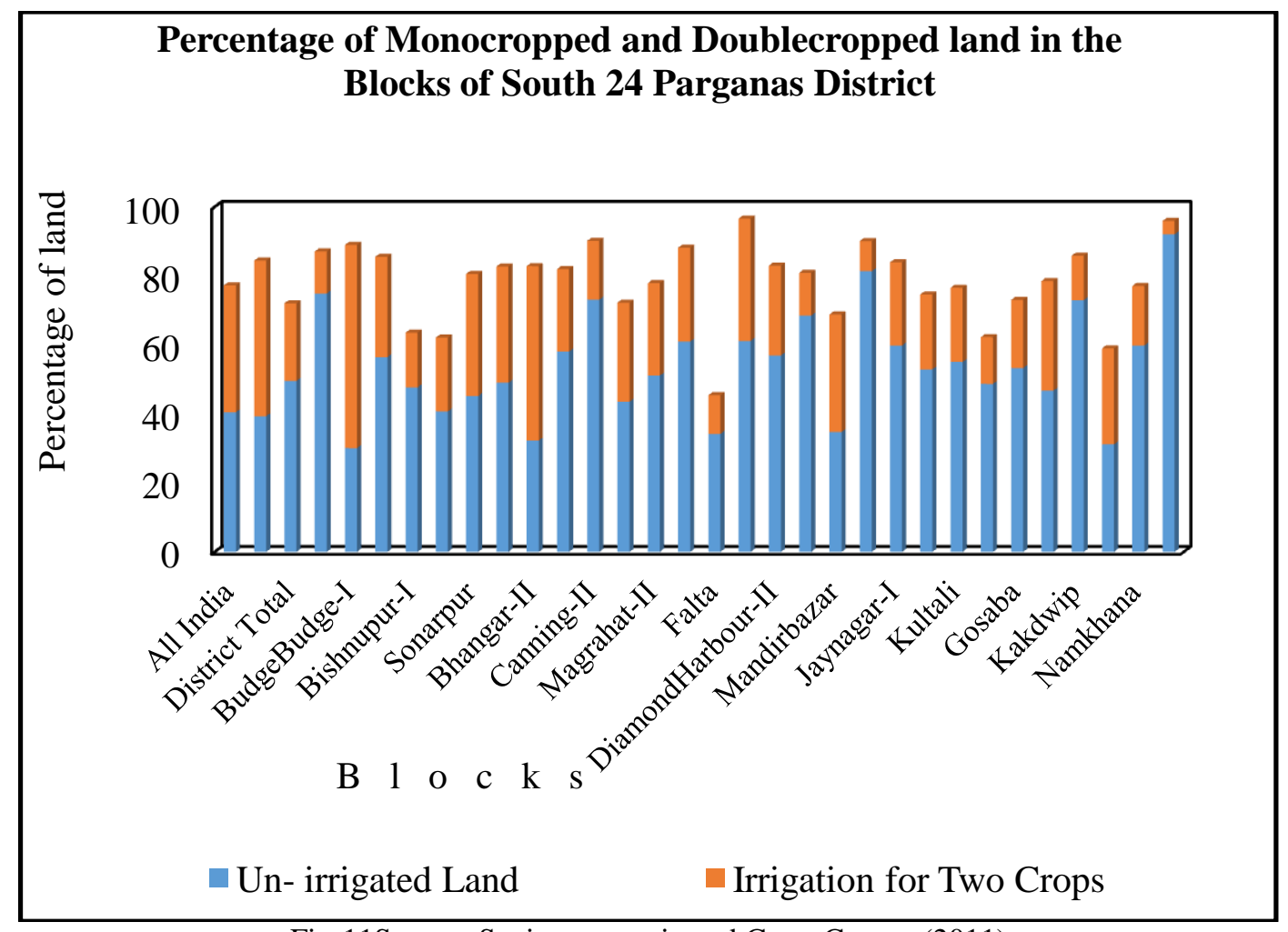

Fig-11Source: Socio-economic and Caste Census (2011)



d)Agriculture:

Fig-12Source: Socio-economic and Caste Census-2011

Agriculture in this district is totally rain fed. Only 13.08 percent of land is irrigated among total cultivated area. In Budge budge-I and Bhangore-II block more than 50 percent cultivated area is double cropped. Observing the livelihood pattern it may be opined that most of the people are engaged in agriculture as agricultural labourer. In 
the kharif season they are engaged in agriculture but during rest of the yearthe local people are forced to migrate all over India as farming is not possible for scarcity of water. So non-working population is 57 percent in this District. Analysing the rice producing area, it has been observed that aman paddy (produced in rainy season) producing area is much more than other two types of paddy- aus and rabi. (Fig-12)

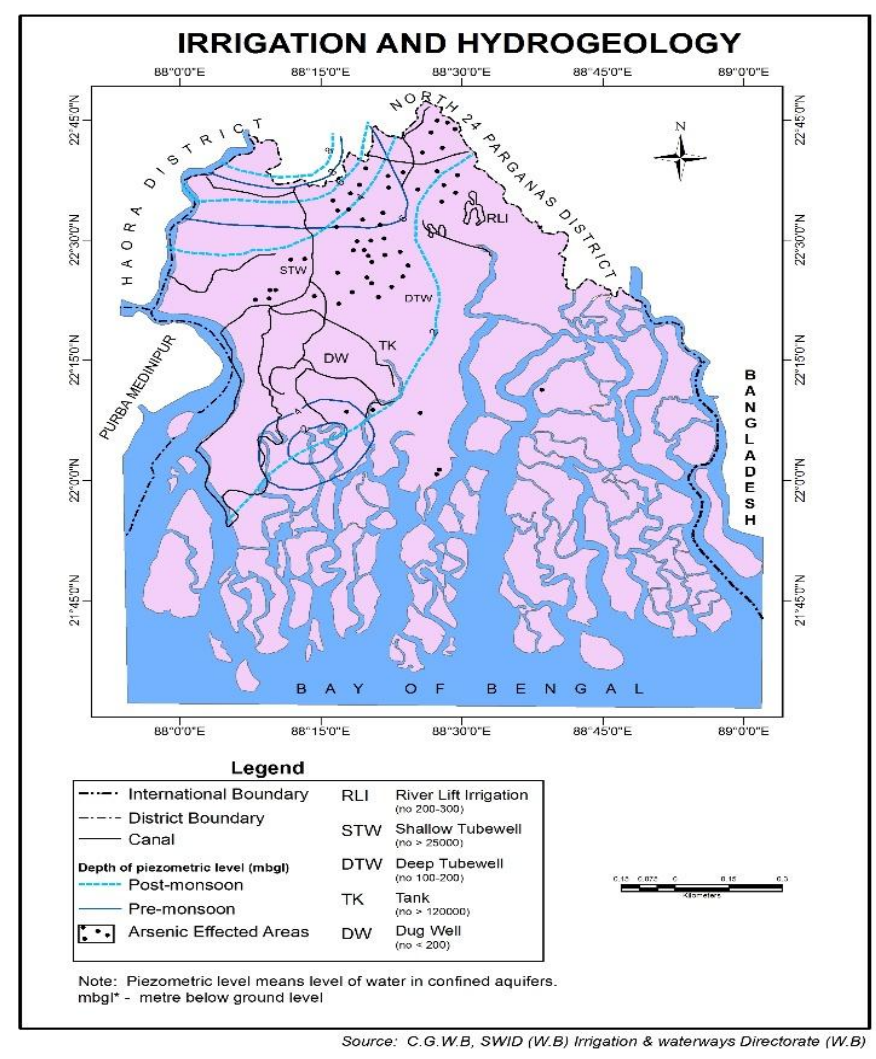

Fig-13 e) Industrial Use of Water:

Large scale industries in this district are located in Budge Budge municipal area and in Bantala of Bhangar-I block. Budge budge industrial zone collects water from Hugli River and Bantala leather complex collect water from Bhangar Kata Khal. If fresh water was available various large or medium scale industries could be established all over the district.

\section{f) Navigation:}

Waterways is one of the important mode of transport in this district, because of island location of the vast area. Time distance is always high in this mode of transport, but no other option is left for the remote islanders. Scarcity of water has a huge formidable impact on navigation in the winter and summer months. Total navigation system has to follow the tidal time span even in case of emergency. Rainy season also is not safe for this mode of transport because of the lack of proper management. Boat capsize is a regular phenomenon in this district especially during the rainy season. Following are the number of ferry services block-wise in this district:

\begin{tabular}{|l|c|l|c|}
\hline \multicolumn{1}{|c|}{ Blocks } & $\begin{array}{c}\text { No. of Ferry } \\
\text { Services }\end{array}$ & \multicolumn{1}{c|}{ Blocks } & $\begin{array}{c}\text { No. of Ferry } \\
\text { Services }\end{array}$ \\
\hline Budge-Budge-II & 4 & Mograhat-II & 1 \\
\hline Jaynagar-I & 2 & Falta & 2 \\
\hline Jaynagar-II & 1 & Diamond Harbour-I & 1 \\
\hline Kultali & 13 & Diamond Harbour-II & 5 \\
\hline Canning-I & 1 & Mathurapur-II & 6 \\
\hline Canning-II & 1 & Kakdwip & 18 \\
\hline Basanti & 10 & Namkhana & 5 \\
\hline Gosaba & 30 & Sagar & 4 \\
\hline Mograhat-I & 1 & Patharpratima & 43 \\
\hline
\end{tabular}

Source: District Statistical Handbook, 2014 
Impact on Health: Scarcity of water has enormous impact on health. Generally distance of the hand pump is more than 100mt from household all over the district. In the summer months when most of the hand pumps fail to supply water due to fall of water level the situation worsens. Women and children are the worst sufferers, because they have to collect drinking water for the household. Use of pond water increases with the march of time though quality of pond water is always questionable for human use. On the other hand in the rainy season due to lack of hygiene consciousness the water borne diseases increase several times. All over the year the district has recorded alarming rate in case of water borne diseases. Mandirbazar, Budge Budge-I, Mograhat-I and II blocks have higher incidence of waterborne disease. Analysing the temporal trend of water borne diseases (Fig-14) it is evident that Diarrhoea is the main disease. Water scarcity and ignorance are the two vital factors controlling this disease

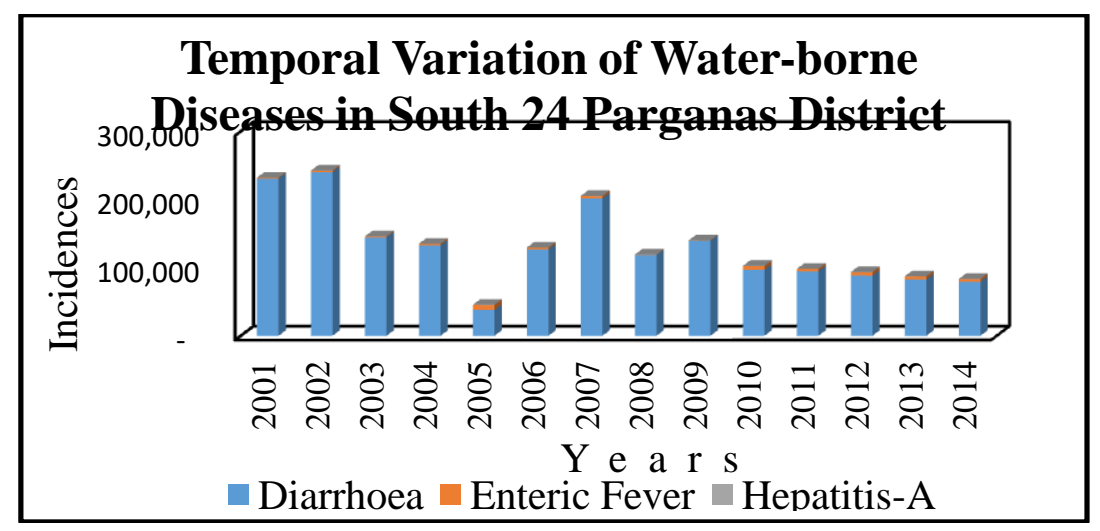

Fig-14Source: CMOH, South 24 Parganas

\section{CONCLUSION}

The increasing demand of fresh water for drinking, irrigation, fishing and navigation is the matter of utmost urgency in this District. The optimal use of this precious resource need proper planning and management by the Government or any other related authority. Various research organisations are working on this issue recently. Water conservation through rain water harvesting is widely practised now all over the district. Administration in this district has given priority in conservation of through rain water harvesting, pond excavation, waterbody renovation and conservation through community participation in Mahatma Gandhi National Rural Employment Guarantee Scheme (MGNREGS). Another important matter deserves to mention that the District is water starved physically and ground water level is gradually depleting; so it is necessary to maintain minimum pumping hours and also to select suitable cropping pattern which will be economically viable and environmentally sustainable.

\section{REFERENCES}

[1] Basu R. and Bhaduri S. (2006) Linkage of Rivers in India- An Appraisal: Society Development and Environment; Progressive Publishers, Kolkata

[2] Bhaduri S. (2006): Emerging Issues in Geography; Academic Staff College and Department of Geography, University of Calcutta, Kolkata

[3] 3. Chary S.N. and Vyasulu V. (2001): Environmental Management: An Indian Perspective; Macmillan India Limited, New Delhi

[4] Das Subhajyoti (2011) : Groundwater Resources of India ;National Book Trust, India

[5] Gurgar R. and Jat B.C. (2008): Geography of Water Resources; Rawat Publications, New Delhi

[6] Government of West Bengal (2009); Water Resource and its Quality in West Bengal; West Bengal Pollution Control Board, Kolkata

[7] Government of India (2009): Bhu-Jal News; Central Ground Water Board; Faridabad, Haryana

[8] Mandal A.K.(2003) : The Sundarbans of India; A development analysis; Indus Publishing Company, New delhi

[9] Santra A.(2012): Geostatistical and Quantitative Approaches for Resource estimation; Firma KLM Pvt. Ltd., Kolkata

[10] Sinha U.P. (2011): Sustainable Resource Development; Concept Publishing Company Pvt. Ltd., New Delhi

[11] United Nations Development programme; Human Development Report, (2006): Beyond Scarcity: Power, Poverty and the Global Water Crisis; Noida, India

[12] Uberoi N.K. (2010): Environmental Management; Excel Books, New Delhi 